\title{
Dutch Managerial Leadership Strategies: Managing Uncertainty Avoidance, Feminine-Related Social Roles, Organisation Prosperity Focus, and Work Orientation within A Polder Framework
}

\author{
Christopher Selvarajah \\ Swinburne University of Technology \\ E-Mail: cselvarajah@swin.edu.au \\ Denny Meyer \\ Swinburne University of Technology \\ E-Mail: cselvarajah@swin.edu.au
}

Andre de Waal

The HPO Center, Hilversum, the Netherlands

E-Mail: andrewaal@planet.nl

Beatrice Van der Heijden

1. Radboud University, Institute for Management, Nijmegen, the Netherlands

E-Mail: b.vanderheijden@fm.ru.nl

2. Open University of the Netherlands

3. Kingston University, London, UK

4. Hubei University, Wuhan, China

\begin{abstract}
This paper extends Schama's (1988) notion of moral geography where there is a determinacy link between an ecology and those managing organisations within it. We emphasise that the link is framed by its historical legacy of social ideals. This paper hypothesises that the egalitarian influence of the polder philosophy leads Dutch managers to value cooperative partnership based on consensus decision-making, in a symbiotic relationship between the manager and the community. Structural equation modelling of the data obtained from surveying 808 managers across occupational industry sectors in the Netherlands support this hypothesis. Results reveal that in the Netherlands (1) the external environment has an unique influence, through its impact
\end{abstract}


on managerial behaviour; (2) the external environment has a profound influence on managers' personal qualities underpinned by their feminine-value-oriented social roles; and (3) organisational prosperity and work orientations are driven by environmental uncertainty avoidance and managers’ feminine-valued social roles.

Keywords: Uncertainty Avoidance, Social Roles, Organisation Prosperity, Work Orientation, Preferred Leadership Styles, Polder Philosophy

\section{INTRODUCTION}

In this paper, we explore leadership as a human phenomenon embedded in culture (Koh, Fernando and Spedding, 2018; Franz and Jain, 2017; Ciulla, 2008). In the context of cultural embeddedness, Luhmann (2017) and Wittfogel (1957) explained that power was influenced by its environment. Wittfogel's 'hydraulic society' expresses the need for large-scale coordinated and directed group activity undertaken over a wide territorial area with a centralised bureaucratic management of the affairs of the society; one that involves large-scale and government-managed works of irrigation and flood control. Following Wittfogel (1957), Welzel (2013), working on decades of World Values Survey ${ }^{1}$ data, proposed that the ecology of human evolution, since the emigrations from the African Rift Valley that have evolved over 50,000 years, varies over two main types of adaptive ecologies.

(1) There were key survival responses to natural resources, especially in tropical river valleys. Water control could prevent flooding, but allow for annual regeneration of fertility via controlled irrigation, food storage to, and in the absence -- due to population density and land shortage -- of hunting and gathering, strong public discipline over resource ownership and re-allocation, over defense and taxation, and provision of a physical and administrative infrastructure to sustain high population densities. This ecology accounts for most human evolution since the emigration from the African Rift Valley 50,000 years ago. It leads to authoritarian leadership and government bureaucracy as necessary for group survival.

\footnotetext{
${ }^{1}$ The World Values Survey (WVS) Association, Sweden was founded in 1981 as a non-profit organisation. WVS is a global research project that explores people's values and beliefs, how they change over time and what social and political impact they have. It is carried out by a worldwide network of social scientists who have conducted representative national surveys in almost 100 countries.
} 
(2) Other ecologies have had permanently available steady supplies of cool water via rain, plus vast areas of land for hunting and gathering, as in the plains of Northwest Europe. The low density population's survival response led to greater small group autonomy, individualism/freedom, consensus, and antiauthoritarian societies, like the Dutch.

Cool water ecologies have emerged in democracies with all their underpinning (but societally varied) ideologies. None have lapsed into despotism as a survival response, so despotism was gradually replaced. Only one cool water society has depended on water control for its survival. It solved the problem with a democratic response of strong implementation, based on consensus and decentralised empowerment animated by a strong civic consciousness. This is missing from the alternative despotic response condition because of the absence of societal trust beyond the particularistic networks. The earlier millennia of socialisation in Northwest Europe led the Dutch to manage water control in a way that was different from societies in which strong government established early, and then (due to path dependency, vested elite interests, and especially compatible ideational structures) stayed totalitarian. These totalitarian states invariably engaged in modern means of propaganda, surveillance and control supported by governmental patrimonialism and organisational paternalism.

Researchers have neglected the links between the ecological conditioning and the managerial response. Dutch society is inclusive, characteristic of a nation that has united against the common threat of an ever-invading sea. The incentive to unite an ethnically diverse population places a premium on polder $^{2}$-driven values as the basis of national identity. In a sense, water management has become symbolic of the polder values of tolerance, respect and liberty (Schreuder, 2001; Sterling, 2013; Wallace, Mathias, and Brotchie, 2013). These polder values are not just a philosophy for the Dutch, but a framework that for the unification of society. Consensus decisionmaking - the hallmark of the polder philosophy (Wallace et al., 2013) - stresses optimal solutions from farmers, shippers, railroads and the public (Sterling, 2013).

The Dutch polder model is a successful consensus-model of the 1990s that is based on the philosophy that employers, trade unions, and the government should solve socioeconomic problems together (Fokkema, et al., 2008). The term polder refers to the combined effort that was required from the Dutch society to reclaim land from the sea and to keep it drained. Dutch society may be characterised as a

\footnotetext{
${ }^{2}$ See the theoretical framework for more explanation of the Polder model.
} 
'consensus democracy' in which citizens participate in political decision-making through their representatives or delegates. These representatives or delegates seek broad-based decision and coalitions to link debate with political decision-making, and to reach their goals through cooperation and compromise (see De Vries, 2014 for an historical overview) (see Woldendorp and Keman, 2007 for a critical reflection of the Polder model).

Yet the form of collegiality that is inherent in the Polder model has been tested as the Netherlands wrestles with changes brought about by globalisation, influences from the European Union, the global financial crisis, and changes in its ethnicity framework based on new migrant populations. The polder philosophy is challenged by these environmental factors and provides the dialogue for this research. In this study, 'the environment' is external to the organisation - private or public - that has the potential to affect its performance. 'Environmental influences', as explained in section 2.1, have the potential to contribute to the performance of the organisation.

There is a Dutch saying: 'God schiep de wereld, maar Nederlanders creëerden Nederland' or 'God created the world, but the Dutch created the Netherlands' (Byun and Ybema, 2005). The formation of a Dutch national identity was an evolutionary process to understand cultural encounters (Frantz and Jain, 2017; Koh, Fernando and Spedding, 201). One such cultural encounter is the Dutch perception of leadership excellence.

The extent to which leaders strive for excellence is critical (Dunning, Leuenberger and Sherman, 1995). Thus, examining perceptions of excellence in the workplace can provide insights on how to best develop effective leaders for specific environments. In this study, the development of preferred leadership styles is presumably easier in the Netherlands where assigning uncertainty avoidance, feminine-valued social roles, power-sharing and work orientation have been influenced by the polder framework.

The remainder of this paper is structured as follows. The excellence in leadership (EIL) model developed by Selvarajah et al. (1995) will be examined. Next the polderdriven cultural variables that permeate the Netherlands (Byun and Ybema, 2005; Feikema, 2004) and influence perceptions of its organisational leaders will be hypothesised. The testing of the resulting hypotheses is then reviewed, followed by this study's empirical results. In conclusion, the implications of these findings and areas of potential future research will be discussed. 


\section{THEORETICAL FRAMEWORK}

As in the Global Leadership and Organisational Behavior Effectiveness (GLOBE) studies (Chhokar, Brodbeck and House, 2008; House, et al., 2004), this study's theoretical framework is founded on implicit leadership theories (ILTs). ILTs identify individual cognitive representations of the external environment; thereby using those preconceived notions to interpret surroundings and control behaviours in the workplace (Lord, Brown and Freiberg, 1999).

Hall (1976), Hofstede (1984), Trompenaars and Hampden-Turner (2009), and the GLOBE studies have based their cultural categorisation on specific dominant cultural value dimensions whilst, in this study leadership perceptions are viewed as knowledge that is mentally organized in the form of schemas or mental structures (Singh 2002). The underlying theory in this study is similar to the cultural models presented by social anthropologists such as D’Andrade (1995), Hinton (1998), and Holland and Quinn (1987), where the cultural frames provide social representation in the form of practice, rituals, customs and language. These cultural models are therefore based on shared ideas, attitudes and modes of behaviour in a society. Hinton (1998: 96) recognised that 'while individual variations exists, some cultural models are salient within a society and may motivate the action of large numbers of individuals'. In other words, a cultural model is a simple mental tool for understanding other people and their environment.

This study relies on this anthropological perspective on Dutch culture and its influence on the perceptions of leader behaviors. The next section explains the development of the EIL model.

\section{The EIL Model}

The EIL model, based on Western and Eastern literature, was developed for the study of managerial leadership in the Asia literature (see Selvarajah, Meyer and Davuth, 2012 for more details). A group of researchers from six Association of South East Asian Nations (ASEAN) -- Brunei, Indonesia, Malaysia, Philippines, Singapore and Thailand - participated in the development of the EIL framework. They isolated 94 value statements on managerial leadership (Selvarajah et al., 1995; Taormina and Selvarajah, 2005), and tasked managers at the Asian Institute of Management in Manila with placing each statement in one of four managerial leadership categories: (1) personal qualities; (2) managerial behaviours; (3) organisational demands; and (4) environmental influences. This data reduction through a Q-Sort procedure resulted in 58 statements. The participants were then tasked with ranking the 10 statements they believed contributed most to leadership excellence. This became the fifth category, 
'Excellent Leader'. These five constructs, central to the EIL framework, are defined next (Selvarajah, Meyer and Donovan, 2013a, p. 359):

Excellent Leadership (EL) describes the combination of behaviours and attitudes desirable for good leadership within a certain cultural context. These good leadership dimensions provided the context-driven base for the preferred managerial leadership styles. Environmental Influences (EI) are external factors that influence the performance of the entire organisation. These influences emphasise the importance of scanning and evaluating the external environment for opportunities. Personal Qualities (PQ) are the personal values, skills, attitudes, behaviours and qualities of an individual. These qualities emphasise morality, religion, interpersonal relationships and communication. Organisational Demands (OD) are the ways a manager responds to the goals, objectives, structures and issues in an organisation. These demands emphasise the importance of organisational prosperity and perhaps at the expense of the individual and wider community. Managerial Behaviours (MB) cover a person's nature, values, attitudes, actions and styles when performing managerial duties. These behaviours emphasise a centralized as opposed to participative work orientation.

These five constructs are universally applicable in the sense that their relationships are critical for understanding ILTs across countries, societies, sectors, industries or organisations. This is demonstrated in much of the EIL research in Asia (see Selvarajah and Meyer 2008a; 2008b; Selvarajah, Meyer and Davuth, 2012; Selvarajah, et al., 2013b; Selvarajah, et al., 2014; Selvarajah and Meyer, 2017; Selvarajah et al., 2017), South Africa (Shrivastava, et al., 2014) and the Netherlands (De Waal, et al., 2011). Thus, the EIL model's leadership perceptions are influenced by national and societal culture. Cultural influences are, therefore, ubiquitous and the EIL framework recognises that it can - and repeatedly does - foster different facets of OD, EI and PQ into sharper relief, which has a bearing on MB and EL perceptions (see figure 1 for a generic EIL framework).

This EIL framework has been validated through cultural value interpretations in several countries. For example, in Thailand these values include non-confrontational style, respect and deference for authority (Selvarajah et al., 2013a). In Cambodia, pragmatism is underscored by Buddhist beliefs, which often influence managerial behaviours (Selvarajah et al., 2012). This study posits that if polder values are as pervasive in Dutch culture as ubuntu is in the South African (Shrivastava et al., 2014), 
and Confucianism is in the Chinese (Selvarajah and Meyer 2008b; Selvarajah, et al., 2013b), then they might affect several EIL variables to produce a unique cultural model for the Netherlands. Accordingly, the next section focuses on polder-driven values to provide a more fine-grained analysis of the affected EIL variables in a Dutch research context.

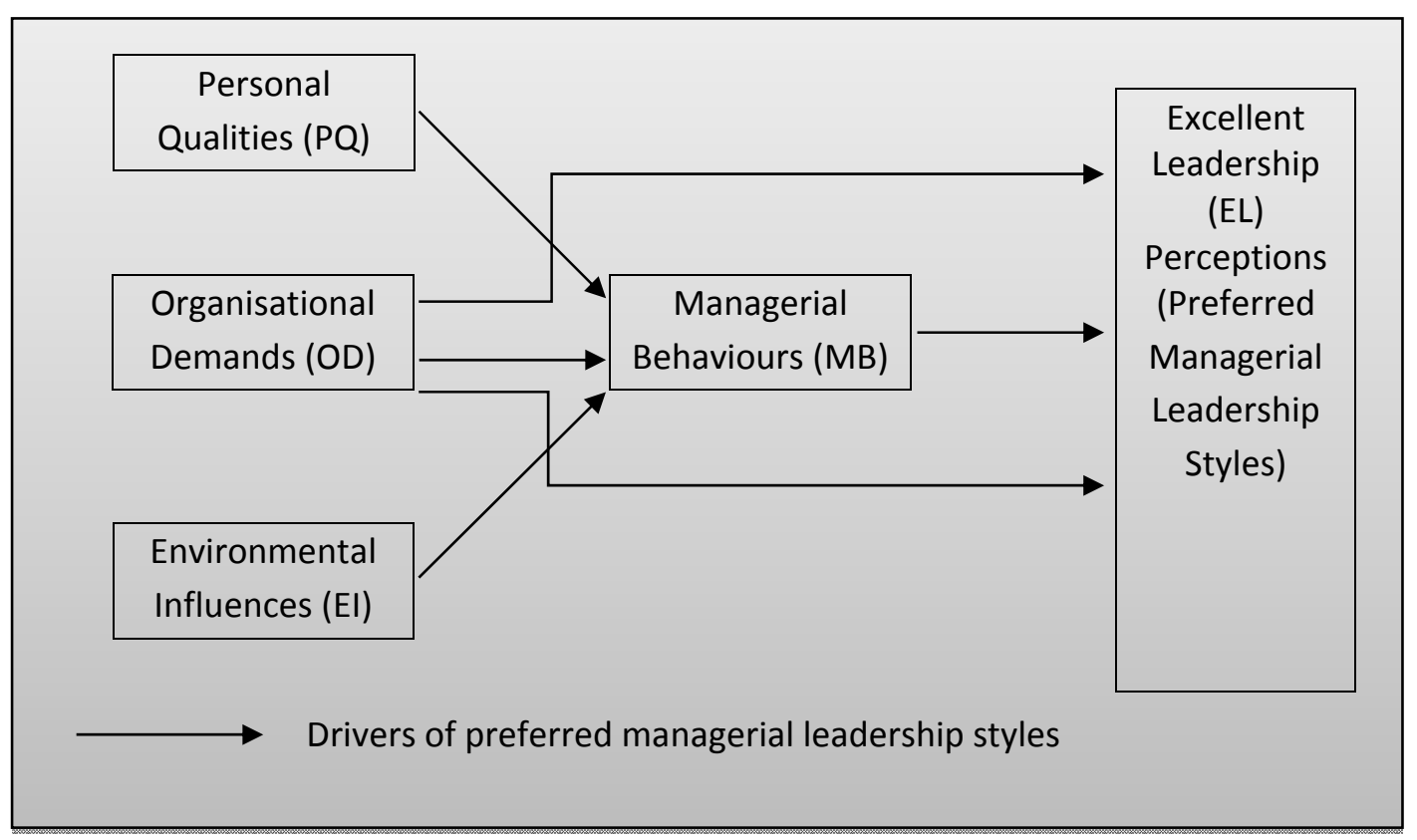

All factors immersed in and influenced bv a ubiauitous culture

Figure 1. The generic EIL

\section{POLDER: A DUTCH WORLDVIEW}

In this study, the polder is positioned as a Dutch cultural framework that has leveraged national convergence around Dutch values (De Vries, 1974; Feikema, 2004; Pley, 1998; Schama, 1988; Wallace et al., 2013). The term, Dutch polder framework, is therefore used as a reference point where leadership behaviours can be explained using cultural interpretations of the Netherlands. In supporting the Dutch polder framework, Schama (1988) asserted that the Dutch cultural values are an extension of what he termed moral geography, which embodies cooperation and consensus as aspects of Dutch traditions. As Feikema (2004: 393) stated, 'In the Dutch culture, morally complex matters are often dealt with in a pragmatic and procedural way as opposed to following a principled approach'. 


\section{Dutch Polder-Driven Framework Supporting Preferred Managerial Leadership Styles}

This section presents a conceptual framework in which the polder values of uncertainty avoidance, feminine-valued social roles, organisational prosperity focus, and work orientation are linked to the EIL dimensions of Environmental Influences, Personal Qualities, Organisational Demands and Managerial Behaviors respectively.

Given the strong environmental influence on the origins of poldering in the Netherlands, it is theorised here that the polder philosophy is environment-driven and will influence EIL-related perceptions of a unique managerial leadership style for the Netherlands, as depicted in figure 2 .

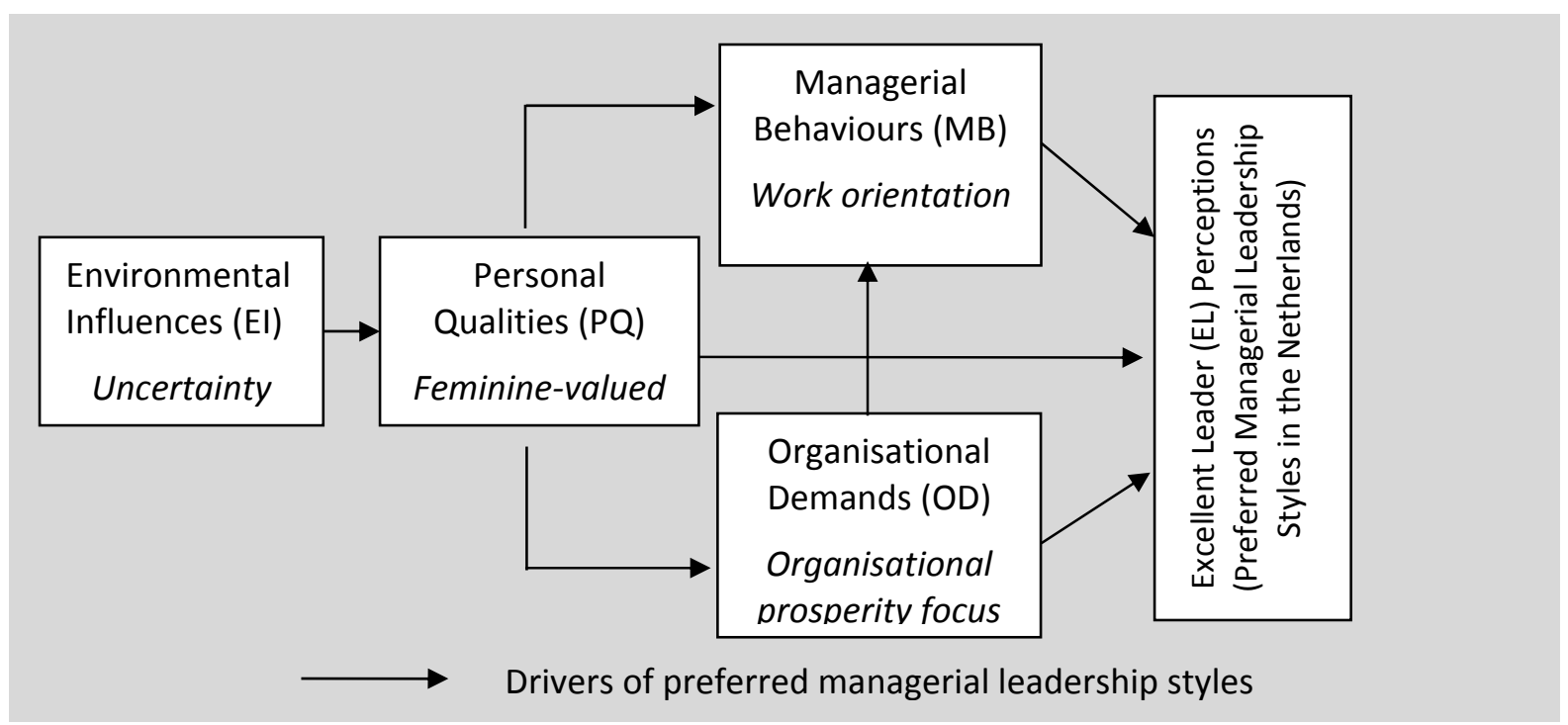

Figure 2 Conceptual framework of preferred managerial leadership style in the Netherlands

Based on this conceptualisation, it is proposed that:

- In the Netherlands, Environment Influences will affect the Personal Qualities of managers in terms of what constitutes preferred managerial leadership styles.

- In the Netherlands, Personal Qualities will influence the Managerial Behaviors and the Organisational Demands as to what constitutes preferred managerial leadership styles.

As reflected by Magsaysay and Hechanova (2017) a fundamental factor in any organisational change is the effectiveness of the leader in fostering change. Furthermore, the polder values depicted in figure 2 provide reference for: 
(1) uncertainty avoidance, where the Dutch seek harmonious development as change occur (Milikowski, 2000);

(2) feminine-valued social roles that support pragmatism, procedural justice and human interdependence;

(3) work orientation that empowers behaviour;

(4) organisational prosperity focus among the constituent bodies of the national economy.

\section{Relating Uncertainty Avoidance to Environmental Influences}

Based on Hofstede's (1984) interpretation, de Waal et al. (2016) defined uncertainty avoidance as the extent to which people in a society or culture are comfortable with ambiguity and uncertainty. Members of societies with high uncertainty avoidance are often anxious in unstructured situations and either avoid or develop strategies to combat them. They tend to prefer a structured workplace, technology, rules and detailed planning. In contrast, members of societies with lower uncertainty avoidance are capable of working in ambiguous situations, taking risks and accepting change. Uncertainty avoidance is particularly relevant in terms of organisational responses to environmental effects.

Miller (1992) identified five generic environmental responses to workplace uncertainty: avoidance; control; cooperation; imitation; and flexibility. He also determined that the associated risks with regard to these five responses often stem from the environment, industry and the organisation. In another study of small- and medium-sized enterprises (SMEs) conducted in Finland, Norway and Sweden, Babakus, Yavas and Haahti (2006: 4) confirmed this link between uncertainty avoidance and environmental influences. They concluded that 'Based on their cultural values [Scandinavians] are low on uncertainty avoidance and therefore are not threatened by environmental uncertainties, and consequently may not feel compelled to engage in networking to reduce uncertainty'.

Managing Environmental Influences thus becomes important for the effectiveness of organisational leadership. Based on this understanding and the Dutch situation of having to deal with environmental conditions both inside and outside of the country, it is postulated here that where uncertainty avoidance is high in organisations, the influence of the environment is likely to have a greater impact on leadership behaviour. Hofstede's (1984) research of more than 50 countries using IBM organisational data revealed that the Dutch rated moderately on uncertainty avoidance, a finding supported in the GLOBE study (Thierry, den Hartog, Koopman and Wilderom, 2008). 
Based on this discussion, the following hypothesis is formulated:

Hypothesis 1: In the Netherlands, unique environmental influences will have a significant effect on the perception of what constitutes preferred managerial leadership.

\section{Relating Feminine-Valued Social Roles to The Personal Qualities of The Manager}

The organisational social roles of managers are influenced by interconnected personal behaviours that transform into obligations, beliefs and norms specified by their status and role in the organisation (Frantz and Jain, 2017; Kahn, et al, 1964). This paper asserts that the personal qualities of managers, which reflect their values, skills and beliefs, influence their behaviour in their organisational roles.

Furthermore, numerous studies have associated the assignment of organisational social roles to the masculinity-femininity dimension (e.g., Dennis and Kunkel, 2004; Hofstede 1984; Powell, Butterfield and Parent, 2002). Studying the personal qualities of leaders in the USA, Dennis and Kunkel (2004) found that while masculinity continues to be associated with organisational leadership, both male and female CEOs who have feminine-valued orientations supported the importance of femininity as a leadership factor. A more recent study by Kark, Waismel-Manor and Shamir (2012) found that femininity was more strongly related to leadership effectiveness than masculinity. Such findings, although contradictory, suggest that in the West there has been a shift towards feminine-value-oriented work situations, which affects what constitutes effective leadership. This highlights the importance of developing personal qualities that support a feminine-valued orientation in egalitarian organisations.

In feminine-value-oriented cultures such as the Netherlands, Hofstede (1984, 2001) identified that the social roles of men and women often overlap and accentuate interpersonal relationships, sympathy and concern for the weak. Although Hofstede did not directly perceive an association between the social roles played by managers and their personal qualities, a significant correlation between them is likely based on culture. Based on this association, managers in Dutch organisations are likely to support personal qualities that emphasise morality, interpersonal relationships and communication - qualities that are often viewed as feminine (Hofstede, 2001). Arrindell and Veenhoven (2002) emphasised that feminine-value-oriented societies such as the Netherlands encourage the feminine-valued traits of modesty, tenderness and concern with quality of life. 
In line with these arguments, the following hypothesis is proposed:

Hypothesis 2: In the Netherlands, a preference for feminine-valued social roles will have a positive influence on the preferred managerial leadership styles.

\section{Relating Organisational Prosperity Focus to Organisational Demands}

At the organisational level, the polder philosophy has two defining attributes: (1) a strong governing authority; and (2) a habitual preference for cooperation and consultation (Peet, 2002). Sterling (2013) believed that such a 'compromise culture' had allowed the Netherlands to weather recent global economic crises. In other words, the country's stakeholders are more concerned with negotiating deals than fighting over principles.

The effects of the economic recession of the 1970s in the Netherlands persuaded trade unions, employers and government bodies to remain committed to consensual politics in what became internationally known as the Polder model (Jones, 2002). Despite the numerous policy changes since the 1970s where the power base transferred from the traditional polder system governed by the ruling elite to organisations and the judicial systems, the consensus decision-making system embedded in the polder values remained (Boonstra and Frouws, 2005). As a result of this transformation, consensus among interest groups was now achieved at lower levels of the sociopolitical hierarchy (Hay, 2004; Pellikaan, Van Der Meer and De Lange, 2003).

Another key value of the Dutch polder framework is a broader community focus in relation to prosperity. The interests of the community outweigh those of organisational prosperity. This value was borne out of necessity, as the Dutch political system is based on a merging of the seven provinces 3 that made up the United Provinces. Major decisions require the support of all the provinces. This paper therefore addresses the dynamics relating to the centrality of organisational decisionmaking values as a measure of organisational demands.

In the Netherlands, the polder philosophy places organisational prosperity within the national cultural dimension, where the relationship between an organisation's performance expectations of its employees and the way employees subsequently behave to satisfy these expectations affects community prosperity. That is, power sharing is as a central concept in achieving 'culturally natured goals' (Torelli and Shavitt, 2010: 704), where culture fosters normative standards for the legitimate use of this power (Chiu and Hong, 2006). Chiu and Hong (2006), and Torelli and Shavitt

\footnotetext{
${ }^{3}$ Hence, the name 'the Netherlands' rather than just 'Netherland'.
} 
(2010), emphasise power as vested in communal-oriented people, where those with relationship exchange orientations behave differently from those that are organisationcentred. Therefore, in support of the polder philosophy of seeking a compromise culture, legitimate use of power is seen to engage community prosperity. Due to culture's relationship with organisational behaviours, it is proposed here that power structures in an organisation may enhance excellence in leadership when there is a similar level of power sharing. Sterling (2013) asserted that in the Netherlands, power is shared with stakeholders seeking optimal solutions in organisational decisionmaking. This is consistent with the view that a pragmatic cooperative framework rather than centrality of power is the hallmark of polder philosophy (Boonstra and Frouws, 2005; Schama, 1988).

A devolved decision-making power structure such as in the Netherlands suggests an egalitarian system of shared power that has greater interdependence in decisionmaking and communality than one that has centralised power (Winsemius, 2010). Managerial behaviours that emphasise executive decision-making are therefore more common in organisations with a centralised organisational culture, and less common in those with a strong interdependence between organisational stakeholders. The following hypothesis is therefore put forward:

Hypothesis 3: In the Netherlands, where the common good is emphasised, organisation demands that allow for the sharing of power and responsibilities is the preferred managerial leadership style.

\section{Relating Work Orientation to Managerial Behaviours}

As Mullins (2002) argued, it is important to build organisational relationships that influence and empower the behaviours and actions of others to reach their potential to achieve organisational success. Moreover, in the Netherlands organisations emphasise lower executive-level decision-making, a more participative management style, and greater dependency between organisational levels (Boonstra and Frouws, 2005). Thus, an egalitarian decision making behavioural framework is preferred, marked by respect for, individual work, work engagement, problem solving, and trusting employee integrity in decision making across levels.

Based on these arguments in relation to centralised versus communal decisionmaking, the following hypothesis is formulated:

Hypothesis 4: In the Netherlands, where there is greater dependence between levels, consultative managerial behaviours are positively related to the 
preferred leadership styles. This suggests low centralised Managerial Behaviours and a preference for a more participative style of leadership.

\section{METHODOLOGY}

This study has considered the common characteristics of Dutch managers at all levels in a standard organisation in the Netherlands. A managerial position is defined as one in which the manager has at least one subordinate. Potential respondents who were managers in the Netherlands were approached online via the website of the country's largest management periodicals, Management Team, and through a formal approach to 25 organisations that were known to one of the authors. As the average number of visitors to Management Team is unknown, an accurate response rate could not be calculated. Furthermore, the identification of respondents including their organisation was kept anonymous to increase the response rate. A total of 808 usable questionnaires was received.

Table 1 shows the demographic characteristics of the respondents. The largest industry represented in the sample was professional services, which included financial, accountancy and consultancy services (28.3\%), followed by education (21.3\%) and construction $(10.6 \%)$.

Table 1 Demographic details of respondents

\begin{tabular}{|c|c|c|c|c|c|c|c|}
\hline Age & $\%$ & $\begin{array}{c}\text { Organization } \\
\text { type }\end{array}$ & $\%$ & Industry & $\%$ & Gender & $\%$ \\
\hline Under 35 & 12.9 & For profit & 59.7 & $\begin{array}{c}\text { Professional } \\
\text { Services }\end{array}$ & 28.3 & Male & 64 \\
\hline $35-40$ & 20.2 & Not-for-profit & 40.3 & Education & 21.3 & Female & 36 \\
\hline $41-45$ & 19.9 & & & Construction & 10.6 & & \\
\hline $46-50$ & 20.2 & & & Healthcare & 9.5 & & \\
\hline $51-55$ & 24.8 & & & Government & 7.7 & & \\
\hline \multirow[t]{3}{*}{ Over 55} & 2.1 & & & Manufacturing & 6.8 & & \\
\hline & & & & IT & 4.5 & & \\
\hline & & & & Other & 0.3 & & \\
\hline
\end{tabular}

Base: $n=808$

\section{MEASURES}

The respondents were asked to rate the importance of each of Selvarajah et al.'s (1995) 94 behavioural value statements based on what constitutes an excellent leader in their position using an importance rating scale ranging from 1 (very unimportant) to 5 (very important). In this way the questionnaire identified which managerial values 
most contributed to perceptions of good leadership in an organisation. This line of enquiry was also used to develop preferred context-specific managerial leadership styles. Using principal component analysis for all 94 behavioural items, Harman's (1976) method suggested that common-method bias was unlikely because less than $20 \%$ of the variation in leadership excellence measures was explained by the first principal component.

In this study, those behavioural items which featured in the original Q-Sort technique described in Selvarajah et al. (1995), and additional items (i.e. 'be socially and environmentally responsible', 'identify social trends which may have an impact on the work', 'respect the self-esteem of others', 'return favours', and 'accept that others will make mistakes') found to be significant in other studies (e.g. Selvarajah and Meyer, 2006, 2008a, 2008b; Selvarajah et al., 2012, 2013a, 2013b; Selvarajah, Meyer, Vinen and Trung, 2010; Selvarajah et al., 2014) were used to create the five EIL constructs. The fifth measure is an overall measure for leadership excellence based on those items that the Q-Sort considered to be the epitome of leadership in any organisational context. This measure was used to create a formative rather than a reflective model for preferred managerial leadership styles.

This study applies a formative model for leadership excellence. A formative model for leadership excellence treats Personal Qualities, Environmental Influences, Organisational Demands and Managerial Behaviors as predictors of preferred managerial leadership styles; a reflective model regards them as indicators of the preferred styles. This approach also offers some protection against common-method bias - this decreases when additional independent variables are included in a regression equation, because controlling for several predictors means that the common-method variance is effectively removed, allowing the true effect of each predictor to emerge (Siemsen, Roth and Oliveira, 2010).

In this study, confirmatory factor analysis using AMOS 22 was conducted to test whether the Excellence in Leadership (EIL) model was observable in the Dutch context. This consisted of generating separate measurement models for the four hypothesized predictors of leadership, as well as the Excellent Leader construct (see tables A1 to A5 in the Appendix). Cronbach's alpha and a composite reliability measure are used to check the reliability of the scales

Based on these analyses, the measurement models showed an acceptable fit (Byrne, 2010) with Goodness of Fit Indices (GFI, AGFI, CFI, TLI) all above 0.90, a Standardized Root Mean Square Residual (SRMR) below 0.05, and a Root Mean Square Error of Approximation (RMSEA) below 0.06, for all five constructs. Tests for discriminant validity were carried out for the four predictor constructs using the nested 
models approach of Bagozzi, Yi and Phillips (1991). The fit for the combined measurement model deteriorated significantly when any of the correlations among these four constructs were set to 1 , confirming these were indeed four distinct constructs. As shown in table 2 in section 6, the correlations between the resulting scales for the four predictor constructs and Excellent Leader had a maximum value of 0.71 , further supporting the discriminant validity of these measures. Scales with a Cronbach's alpha above 0.70 are regarded as reasonably reliable with values above 0.80 indicating good reliability. Values above 0.60 are considered adequate for an exploratory study such as this (Hair, Anderson, Tatham and Black, 2006). Similarly values above 0.60 are considered adequate for composited reliability (Hair, Hult, Ringle and Sarstedt, 2017) even when average variances extracted are low (Fornell and Larcker, 1981).

These results confirmed that the proposed excellence in leadership measures originally derived for an Asian context also supported the development of preferred managerial leadership styles in the Dutch context.

\section{RESULTS}

As shown in table 2, the average scales for four of the five constructs exhibited reliabilities above 0.65 for Cronbach's alpha. Only reliability for Environment Influences was slightly lower with a Cronbach's alpha of 0.61. Similarly, the Composite Reliabilities (CR) always exceeded 0.6, despite low average extracted variances. All the correlations were significant $(\mathrm{p}<.001)$.

Table 2 Descriptive Statistics for Scales

\begin{tabular}{|c|c|c|c|c|c|c|c|c|c|c|}
\hline & Variable & M & SD & $\alpha$ & $\sqrt{ } \mathrm{AVE}$ & CR & 1 & 2 & 3 & 4 \\
\hline 1 & $\begin{array}{l}\text { Excellent } \\
\text { Leadership (EL) }\end{array}$ & 4.42 & 0.388 & 0.749 & 0.53 & 0.756 & & & & \\
\hline 2 & $\begin{array}{l}\text { Environmental } \\
\text { Influences (EI) }\end{array}$ & 3.74 & 0.494 & 0.606 & 0.48 & 0.622 & 0.53 & & & \\
\hline 3 & $\begin{array}{l}\text { Organizational } \\
\text { Demands (OD) }\end{array}$ & 3.91 & 0.465 & 0.662 & 0.48 & 0.669 & 0.64 & 0.61 & & \\
\hline 4 & $\begin{array}{l}\text { Personal Qualities } \\
\text { (PQ) }\end{array}$ & 4.15 & 0.380 & 0.765 & 0.48 & 0.778 & 0.71 & 0.57 & 0.62 & \\
\hline 5 & $\begin{array}{l}\text { Managerial } \\
\text { Behaviors (MB) }\end{array}$ & 3.79 & 0.412 & 0.669 & 0.44 & 0.675 & 0.64 & 0.57 & 0.65 & 0.67 \\
\hline
\end{tabular}

Base: $n=808$ 
Structural equation modelling (SEM) was then used to test whether the Excellent Leader scale was predicted by the four constructs of leadership: Environmental Influences; Personal Qualities; Managerial Behaviours; and Organisational Demands. In this model, these four dimensions represent a formative model of Excellent Leadership for identifying preferred managerial leadership styles in the Netherlands. The model shown in figure 3 explains 58\% of the variance in Excellent Leadership, and providing satisfactory goodness of fit (Chi-square $=1.292$; $\mathrm{df}=1 ; p=0.256$ ).

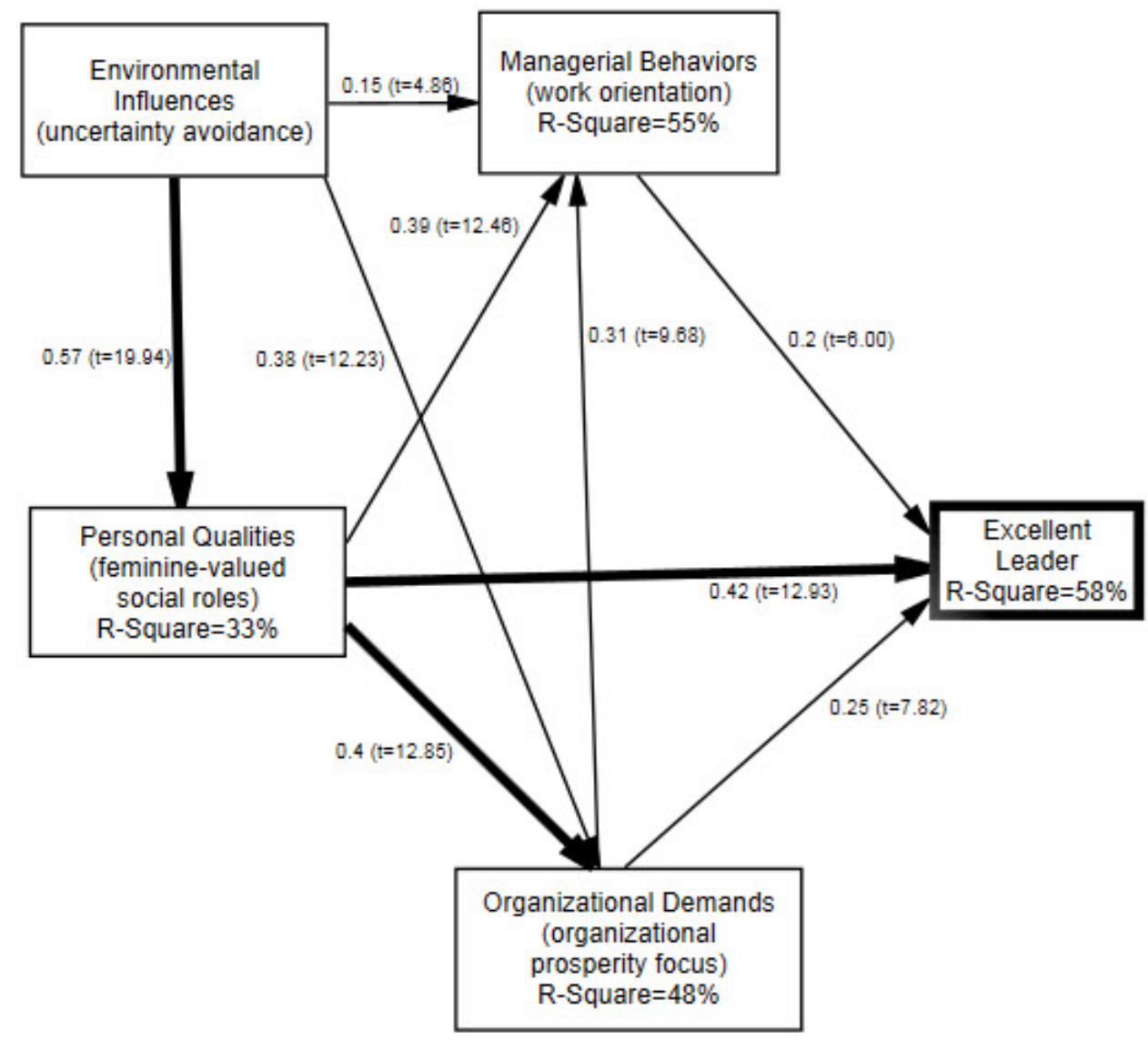

Figure 3 Structural Model for Preferred Managerial Leadership in The Netherlands ${ }^{4}$

\footnotetext{
${ }^{4}$ Values in brackets are polder values; with thicker lines for loadings equal to or greater than 0.40
} 
The beta coefficients and explained variance associated with each dimension (construct) are also shown in figure 3, which fully supports the original model in figure 2 except that in the former model it was hypothesised that Personal Qualities completely mediates the relationship between Environmental Influences and the constructs of Managerial Behaviours and Organisational Demands. In contrast, in figure 3, Personal Qualities only partially mediates these relationships in that there are also direct but weak links between Environmental Influences and the constructs of Managerial Behaviours and Organisational Demands. However, as theorised, there is no direct link between Environmental Influences and perceptions of Excellent Leader; herewith supporting the conceptualisation suggested in figure 2 and providing some evidence for the mediation effects of Personal Qualities.

The top row of table 3 shows the overall standardised effect sizes for each of the four constructs that support Excellent Leader in organisations in the Netherlands. The predictive power of the independent variables clearly suggests that in the EIL framework, Personal Qualities of the manager is the strongest indicator of Excellent Leadership $\left(\eta^{2}=0.622\right)$, followed by Environmental Influences $\left(\eta^{2}=0.506\right)$, Organisational Demands $\left(\eta^{2}=0.310\right)$ and Managerial Behaviours $\left(\eta^{2}=0.201\right)$. However, the 95\% confidence intervals (CI) generated using 1,000 bootstrap samples appeared to overlap to some extent, suggesting that Personal Qualities and Environmental Influences have similar importance, while Managerial Behaviours and Organisational Demands also have similar but less importance.

As a final step, invariance tests were conducted to establish whether the same model weights could be used for males and females (chi-square $=26.959$; $\mathrm{df}=9$; $p=$ 0.001 ), across all age ranges (chi-square $=80.98$; $\mathrm{df}=36 ; p<0.001$ ), and for profit versus not-for-profit organisations (chi-square $=25.88$; $\mathrm{df}=9 ; p=0.002$ ). In all test cases, different weights were required for the categories. Yet as shown in table 3, the ordering of the four constructs determining what constitutes Excellent Leader remained the same in all cases except for the 36-40 age group, suggesting that cultural influences on perceptions of managerial leadership excellence are consistent across gender, age and organisation groups in the Netherlands.

The managers in the 36-40 age group rated Managerial Behaviours above Organisational Demands, but otherwise the ranking of the constructs is as follows: (1) Personal Qualities; (2) Environmental Influences; (3) Organisational Demands; and (4) Managerial Behaviours. This supports this study's hypotheses that Dutch managers perceive the importance of the feminine-valued social roles and influence of the environment. However, there was less support for the hypotheses relating to shared 
power and responsibilities (organisational demands) and consultative managerial behaviours.

Table 3 EIL's Total standardised Effect Sizes for The Prediction of Excellent Leader

\begin{tabular}{|c|c|c|c|c|c|}
\hline $\begin{array}{l}\text { EIL } \\
\text { Constructs } \\
\text { Polder } \\
\text { values }\end{array}$ & $\begin{array}{c}\text { Personal } \\
\text { Qualities } \\
\text { Feminine- } \\
\text { valued } \\
\text { social roles }\end{array}$ & $\begin{array}{l}\text { Environmental } \\
\text { Influences } \\
\text { Uncertainty } \\
\text { avoidance }\end{array}$ & $\begin{array}{l}\text { Organisational } \\
\text { Demands } \\
\text { Organisational } \\
\text { prosperity focus }\end{array}$ & $\begin{array}{c}\text { Managerial } \\
\text { Behaviors } \\
\text { Work } \\
\text { orientation }\end{array}$ & $\begin{array}{c}\text { R-square } \\
(\%)\end{array}$ \\
\hline Overall & 0.622 & 0.506 & 0.310 & 0.201 & 58.3 \\
\hline $95 \%$ CI & $\begin{array}{c}0.560 \\
\text { to } 0.701\end{array}$ & $\begin{array}{c}0.442 \\
\text { to } 0.602\end{array}$ & $\begin{array}{c}0.247 \\
\text { to } 0.359\end{array}$ & $\begin{array}{c}0.133 \\
\text { to } 0.277\end{array}$ & $\begin{array}{c}50.8 \\
\text { to } 69.7\end{array}$ \\
\hline Males & 0.599 & 0.523 & 0.343 & 0.200 & 57.7 \\
\hline Females & 0.657 & 0.485 & 0.340 & 0.164 & 61.3 \\
\hline For profit & 0.621 & 0.551 & 0.364 & 0.203 & 61.6 \\
\hline $\begin{array}{l}\text { Not-for- } \\
\text { profit }\end{array}$ & 0.600 & 0.411 & 0.296 & 0.166 & 51.2 \\
\hline Under 35 & 0.500 & 0.495 & 0.316 & 0.153 & 46.5 \\
\hline $36-40$ & 0.539 & 0.377 & 0.260 & 0.346 & 46.2 \\
\hline $41-45$ & 0.723 & 0.589 & 0.365 & 0.135 & 73.0 \\
\hline $46-50$ & 0.605 & 0.498 & 0.330 & 0.182 & 57.1 \\
\hline 51 plus & 0.562 & 0.511 & 0.381 & 0.108 & 55.2 \\
\hline
\end{tabular}

\section{DISCUSSION}

The main purpose of this study was to explore cultural embeddedness by empirically studying the link between an ecology and the managing organisations within it. In so doing, this study also tested an organisational leadership model developed within an Asian context in the Netherlands. In the Netherlands, polder values were factored in to offer a more fine-grained analysis of the EIL variables. Dutch cultural values were used to help define Dutch management styles via the polder philosophy and the four-construct EIL model consisting of Environmental Influences, Personal Qualities, Organisational Demands and Managerial Behaviours. The relationships between the EIL constructs within the cultural context of the Netherlands using SEM were also tested. 
This study is based on the understanding that the EIL framework does not provide a framework that can be structured the same across all countries or cultures. Each country's model would be unique, with the potential to develop sub-constructs to explain the cultural context of each environment. The EIL framework in this study supports an emic cultural context - one in which the analysis of the cultural phenomenon is from the perspectives of the individuals being studied.

Table 4 summarises the support found for this study's hypotheses, using bootstrapped 95\% CI for the standardized total effect sizes. In particular, there is strong support for the view that feminine-valued social roles (Personal Qualities) and uncertainty avoidance (Environmental Influences) are a priority of excellent leaders in the Netherlands, while consultative processes (Managerial Behaviours) and power and responsibility sharing (Organisational Demands) have significantly less importance.

Table 4 Polder Value Supported Hypotheses

$\begin{array}{lccc} & & \text { Total } & \\ \text { Hypotheses } & \text { Corresponding } & \text { standardized } \\ \text { effect size } & \text { Importance } \\ & & (95 \% \mathrm{CI}) & \end{array}$

H1. In the Netherlands, the unique environmental influences will have a significant effect on the perception of what constitutes preferred managerial high Influences (EI) (0.442:0.602) importance leadership styles.

H2. In the Netherlands, a preference for feminine-valued social roles will have a positive influence on the preferred managerial leadership styles.

$\begin{array}{ccc}\text { Personal } & 0.622 & \text { high } \\ \text { Qualities (PQ) } & (0.560: 0.701) & \text { importance }\end{array}$

H3. In the Netherlands, where the common good is emphasised, organization demands that allow for the sharing of power and responsibilities is the preferred Organizational
Demands
(OD)

$\begin{array}{cc}0.310 & \text { low } \\ (0.247: 0.359) & \text { importance }\end{array}$
managerial leadership style.

H4. In the Netherlands, where there is greater dependence between levels, consultative managerial behaviours are positively related to the preferred leadership styles. This suggests low centralized Managerial Behaviours

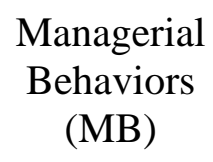
Behaviors (MB)

\author{
0.201
} (0.133:0.277) low
portance and a preference for a more participative style of leadership in the Netherlands. 
As a reflection of figure 3, the relational effects of the EIL model on preferred managerial leadership styles in the Netherlands are discussed in the following subsections. Previous behavioural studies have not measured inter-relational effects, and nation-specific studies have not explored the mediation effects for cultural variances; thus, the value of this study's approach comprises a better understanding of the cultural phenomena underlying managerial leadership styles in the Netherlands and possibly other Western countries.

\section{Uncertainty Avoidance as A Measure of Environmental Influences}

The need to avoid uncertainty is an integral part of environmental scanning, and this is a key influencer of the Personal Qualities of Dutch managers. Uncertainty avoidance is closely related to factors such as economic circumstances, political situations, and cultural and legal elements that affect the success of the organisation (Babakus et al., 2006; Berard and Delerue, 2010; Miller, 1992).

Table A2 (see Appendix) shows external influences, 'multicultural orientation' and fostering an international perspective, as the value statements that contribute most to identifying a manager as a leader in Dutch organisations. Fontaine (2007) is of the view that the Dutch business landscape has changed drastically in the last three decades as more citizens from non-Dutch background have entered the workforce, enhancing the disposition of the Dutch disposition for international trade. Furthermore, the managers in this study agreed that the most important behavioural value statement is 'being socially and environmentally responsible'- indicative of Dutch society's increasing attention to environmental issues.

Therefore, from the perspective of national culture, the value statements clearly suggest a balance that suits multicultural initiatives, internationalisation of the economy, and the creation of a working environment that provides social and environmental accountability.

Avoiding the adverse effect of external influences is an important function of Dutch managers. In the EIL model, the dimension that measures these effects is Environment Influences. The Netherlands have always been a seafaring nation with an outward-looking perspective, and this orientation and combined with its multicultural population are possible drivers of the thinking of Dutch managers.

\section{Feminine-Valued Social Roles as Measure of Personal Qualities}

In the EIL model, a manager's 'soft' and 'hard' qualities are represented by the Personal Qualities dimension, which includes feminine-value-oriented measures that 
promote wider social roles. These personal qualities are often seen as supporting introspection within an organisational culture in the Netherlands.

As shown in table A3 (see Appendix), the Personal Qualities dimension received the highest overall standardised effect size score, indicating that the softer (feminineoriented) values of Dutch culture influence the egalitarian nature of managers with regard to what constitutes an excellent leader. The Dutch believe that the personal behavioural value statements that are most important to managers are 'respecting the self-esteem of others' and 'consistency in dealing with people'. However, Dutch managers have expressed the desire to try harder to respect others and to accept responsibility for their own mistakes where morality, reliability and excellent communication skills are deemed important.

Reliability, as a characteristic of good personal qualities is exhibited with consistent behaviour in interacting with people, and maintaining composure in a crisis, whilst excellent communication skills transform as clear and concise speaking and writing. The Dutch managers insist that the indispensable personal quality for management is the perception of dependability and trustworthiness. Therefore, from the perspective of national culture, Personal Qualities are viewed as highly important in the Netherlands.

\section{Organisational Prosperity Focus as A Measure of Organisational Demands}

In this study, the managers disagreed with the opinion that the Dutch manager's role is solely to support the demands of the organisation. They instead supported the view that the expectations of the organisation should be balanced with the needs of the stakeholders. Table A4 (see Appendix) shows the statements that contribute most to identifying a manager who is excellent in satisfying the demands of an organisation. Such managers have a preference for sharing power, making joint decisions, maximising productivity, and supporting the corporate image. That is, acting as a member of the team is seen as the most important behavioural value when addressing corporate demands.

Joint decision-making in Dutch organisations is therefore commonly carried out where the interests of organisational stakeholders are well-represented. This is where a commitment to the polder values of consensus and corporate partnerships prevails when factoring in organisational prosperity. In the Netherlands, organisations commonly share responsibility or decision-making.

Organisational Demands is viewed as a mediating influence on what constitutes managerial leadership styles in Dutch organisations. However, managers' feminineoriented personal qualities also have a direct influence on what constitutes preferred 
leadership styles. Thus, Organisational Demands, as a determinant of leadership excellence in Dutch organisations, has a weaker but still significant influence on what constitutes an excellent leader compared to the other EIL constructs. Organisational prosperity is important, but not at the expense of the community.

\section{Work Orientation as A Subject of Managerial Behaviors}

In a highly centralised power culture, there is a tendency not to question or challenge authority (Das, DiRienzo, Cort and Burbridge, 2007; Pellegrini and Scandura, 2006). Instead, respect, obedience and deference to higher-status individuals are valued. The dimension that best measures these constructs in the EIL model is Managerial Behaviours, which includes measures such as a manager's ability to make work decisions, prioritise the workload, focus on tasks, and independently make decisions.

As Table A5 shows (see Appendix), the Dutch believe that managers should be quick at decision-making and prioritise their workloads wisely. In addition, these managers should be task-focused, innovative, autonomous and adept at delegating work. In an egalitarian system, autonomy of employees and having managers who trust their work is essential. This is in line with the emphasis for greater autonomy in the Dutch workplace. This means that managerialism - where the primary value is economic efficiency and support for class-consciousness is perceived to be a unifying force among managers (Alvesson, 2004; Alvesson and Sveningsson, 2011; Locke and Spender, 2011; White, Carvalho, and Riordan, 2011) - is relatively unknown in the Dutch corporate system. From a national culture perspective, the Netherlands, characterised by consensus-based decision-making and a highly feminine-valueoriented culture, will attach little importance to Managerial Behaviors as supportive of economic efficiency and a managerial class. Rather, an egalitarian participative style of managerial behaviour is preferred to a more centralised work orientation.

These results imply that managers in the Netherlands view their role as allowing them a certain amount of independence as opposed to purely pursuing centralised control in support of economic efficiency.

\section{CONCLUSION}

The value of this paper to managers is that it improved our understanding of the phenomena underlying managerial styles in the Netherlands. The polder philosophy has a strong influence on the psychological interpretation of life, and therefore heavily influences the culture of Dutch society. The findings suggest that the Dutch organisational systems are geared towards power sharing, which is reflected in most 
business operations where stakeholder representations are valued components of decision-making. This decision-making procedure is enhanced through a consensusbased process rather than the typical anglicised adversarial response; suggesting managerialism as a value base in business operations does not have much support in Dutch organisations.

\section{Limitations and Recommendations for Further Research}

A cross-sectional study like this, using data collected from a single survey instrument, always raises concerns about possible common-method bias, even when a questionnaire has been used successfully for multiple studies in many different countries, as is true in this case. However, this study's results of the principal component analysis of the leadership importance data suggest that less than $20 \%$ of the variability can be explained by the first principal component. According to Harman (1976), this indicates that common-method bias is unlikely to be a problem in such data. Further, the use of a formative rather than a reflective model for leadership excellence ensures the minimisation of any common-method bias in the results.

Another limitation relates to the method of questioning. This EIL study has been conducted from the perspective of managers, not their subordinates, which could be perceived as biased or as self-reporting. However, the intention here was to measure managers' perceptions of their positions in organisations; therefore, seeking followers' perceptions would not have been as relevant.

In addition, as explained by this study's Dutch co-researchers, the term 'polder' has been widely used - even overused - especially in politics and in negotiations among government, employers and employees in the Netherlands. Therefore, a detailed understanding of the Dutch polder framework, its use and potential use should be investigated, potentially via a qualitative study that supports this initiative.

\section{Practical Implications}

As highlighted in this study, the polder philosophy has a strong influence on the psychological interpretation of life, and therefore heavily influences the culture of Dutch society. Its effects can be seen in both the in-group and out-group behaviours. The advantage the Dutch have is accumulated knowledge of the world economy from their seafaring days, and an acute knowledge of the uncertainties they face as a small water-bound nation. This confidence has enabled them to develop a highly pragmatic worldview as regards to systems that enforce egalitarianism. Although we have raised caution about the generalization of gender equality, a sense of fairness prevails in the Netherlands that supports values across gender as well as communal differences. 
The Dutch organisational systems are highly geared towards power sharing, which is reflected in most business operations where stakeholder representations are valued components of decision-making. This decision-making procedure is enhanced through a consensus-based process rather than the typical anglicised adversarial repose. Therefore, managerialism as a value base in business operations does not have much support in Dutch organisations.

What does all this mean for leadership development in the Netherlands?

The excellence-related perceptions generated in this study provide some insights into how best to train and develop effective organisational managers in the Netherlands. Six perceptions are worth exploring as polder values that could reinforce organisational culture in the Netherlands. First, understanding Environmental Influences, especially those of a workforce of multicultural employees, and showing respect for the sensitivities of the social and natural environment are important. Second, the importance of the feminine-oriented social roles that are valued by Dutch managers must be reinforced in an increasingly multicultural organisational framework. Third, power sharing with less emphasis on centralised power provides an important framework that entails and reinforces interdependence among stakeholders, suggesting that organisational prosperity is important, but not at the expense of the community. Fourth, work-oriented behaviours in the Netherlands support decentralised management control, with less emphasis on the managerial prerogative. Fifth, developing strategies that provide incentives for good work and honesty are highly perceived activities among managers. Finally, the polder philosophy that has an underlying unifying effect for the nation needs to be incorporated into human resources capacity-building programs in the Netherlands.

All these efforts will also have implications for expatriate training of foreigners in the Netherlands, and for the adaptation of the Dutch to foreign business cultures.

\section{Declaration of Conflicting Interests}

The author(s) declared no potential conflicts of interest with respect to the research, authorship, and/or publication of this article.

\section{Acknowledgement \& Funding}

We wish to acknowledge the review and suggestions to improve the paper provided by Professor Gordon Redding and Professor Christian Welzel. We are truly indebted to them.

The author(s) received no financial support for the research, authorship, and/or publication of this article. 


\section{REFERENCES}

Alvesson, M. (2004). Knowledge work and knowledge-intensive firms, Oxford: Oxford University Press.

Alvesson, M., \& Sveningsson, S. (2011). Management is the solution: now what was the problem? On the fragile basis for managerialism. Scandinavian Journal of Management 27: 349-361. http://dx.doi.org/10.1016/j.scaman.2011.08.002

Arrindell, W.A., \& Veenhoven, R. (2002). Feminine values and happy life-expectancy in nations. Personality and Individual Differences 33, 803-813. http://dx.doi.org/10.1016/S0191-8869(01)00193-3

Babakus, E., Yavas, U., \& Haahti, A. (2006). Perceived uncertainty, networking and export performance: a study of Nordic SMEs. European Business Review, 18, 413. http://dx.doi.org/10.1108/09555340610639815

Bagozzi, R.P., Yi, Y., \& Phillips, L.W. (1991). Assessing construct validity in organizational research. Administrative Science Quarterly, 36, 421-458. http://dx.doi.org/10.2307/2393203

Berard, C., \& Delerue, H. (2010). A cross-cultural analysis of intellectual asset protection in SMEs. Journal of Small Business and Enterprise Development, 17, 167-183. http://dx.doi.org/10.1108/14626001011041193

Boonstra, W.J., \& Frouws, J. (2005). Conflicts about water: A case study about conflict and contest in Dutch rural policy. Journal of Rural Studies, 21, 297-312.

Byrne, B. (2010). Structural Equation Modeling with AMOS: Basic Concepts, Applications and Programming. Lawrence New Jersey: Erlbaum.

Byun, H., \& Ybema, S. (2005). Japanese Business in the Dutch Polder: The Experience of Cultural Differences in Asymmetric Power Relations. Asia Pacific Business Review, 11, 535-552. http://dx.doi.org/10.1080/13602380500135836

Chhokar, J.S., Brodbeck, F.C., \& House, R.J. (2008) Culture and Leadership Across The world: The GLOBE Book of In-depth Studies of 25 Societies. Psychology Press: New York.

Chiu, C.Y., \& Hong, Y.Y. (2006). Social Psychology of Culture. Psychology Press: New York.

Ciulla, J. (2008). Leadership studies and the "fusion of horizons". The Leadership Quarterly, 19, 393-395.

D'Andrade, R. (1995). The Development of Cognitive Anthropology. Cambridge University Press: New York.

De Waal, A.A; van der Heijden, B.E.J.M; Selvarajah, C, \& Meyer, D. (2016). Comparing Dutch and British High Performing Managers. Journal of 
$\begin{array}{lll}\text { Management } \quad \text { and } \quad \text { Organization. } & \text { 349-366. }\end{array}$ http://dx.doi.org/10.1017/jmo.2015.39

Das, J., DiRienzo, C., Cort, K., \& Burbridge, J.J. (2007). Corruption and the role of information. Journal of International Business Studies, 38, 320-332.

De Vries, J. (1974). The Dutch Rural Economy in the Golden Age 1500-1700. New Haven, CT: Yale University Press.

De Vries, J. (2014). The Netherlands and the Polder Model: Questioning the Polder Model Concept. BMGN-Low Countries Historical Review, 129(1), 99-111. http://dx.doi.org/10.18352/bmgn-lchr.9449

Dennis, M.R., \& Kunkel, A.D. (2004). Perceptions of men, women, and CEOs: the effect of gender identity. Social Behavior and Personality, 32, 155-172. http://dx.doi.org/10.2224/sbp.2004.32.2.155

De Waal, A.A., Van der Heijden, B.I.J.M., Selvarajah, C., \& Meyer, D. (2011). Characteristics of high performing managers in The Netherlands. Leadership and Organization Development Journal, 33, 131-148. http://dx.doi.org/10.1108/01437731211203456

Dunning, D., Leuenberger, A., \& Sherman, D.A. (1995). A new look at motivated inference: are self-serving theories of success a product of motivational forces. Journal of Personality and Social Psychology, 69, 58-68. http://dx.doi.org/10.1037/0022-3514.69.1.58

Feikema, L. (2004). Terminal sedation and the Dutch "polder model”. Ethik in der Medizin, 16, 392-400.

Fokkema, T., De Valk, H., De Beer, J., \& Van Duin, C. (2008) The Netherlands: childbearing within the context of a "Poldermodel" society. Demographic Research, 19(21), 743-794.

Fontaine, R. (2007). Cross-cultural management: six perspectives. Cross Cultural Management: An International Journal, 14, 125-135. http://dx.doi.org/10.1108/13527600710745732

Fornell, C. \& Larcker, D. F., (1981). Evaluating structural equation models with unobservable variables and measurement error, Journal of Marketing Research, 18(1), 39-50. http://dx.doi.org/10.2307/3151312

Frantz, T.L., \& Jain, A.K. (2017). Relating CEO leadership behaviour and organization culture in the Indian context. Leadership and Organizational Development Journal, 38(6), 746-764.

Hair, J. F., Black, W. C., Babin, B. J., Enderson, R. E. \& Tatham, R. L. (2006). Multivariate Data Analysis (6th ed.), . Upper Saddle River, NJ: Prentice Hall, Hair, J. F., Hult, G. T. M., Ringle, C. M. \& Sarstedt, M. (2017). A Primer on Partial 
Least Squares Structural Equation Modeling (PLS-SEM) (2nd ed.) Thousand Oaks, CA:Sage.

Hall, E.T. (1976). Beyond Culture. Garden City, New York: Doubleday. Harman, H.H. (1976). Modern Factor Analysis. Chicago: Chicago Press.

Hay, C. (2004). The normalizing role of rationalist assumptions in the institutional embedding of neoliberalism. Economy and Society, 33(4), 500-527. http://dx.doi.org/10.1080/0308514042000285260

Hinton, A.L. (1998). Why did I kill? The Cambodian genocide and the dark side and face honor. Journal of Asian studies, 57(1), 93-122 http://dx.doi.org/10.2307/2659025

Hofstede, G. (1984). Culture's Consequences: International differences in workrelated values. Thousand Oaks: Sage Publications.

Hofstede, G. (2001). Cultures' consequences: Comparing Values, Behaviors, Institutions and Organisations Across Nations. Sage Publications: Thousand Oaks.

Holland, D., \& Quinn, N. (1987). Cultural Models in Language and Thought. Cambridge University $\quad$ Press: New http://dx.doi.org/10.1017/CBO9780511607660

House, R.J., Hanges, P.J., Javidan, M., Dorfman, P.W., \& Gupta, V. (2004). Culture, Leadership, and Organizations: The GLOBE Study of 62 Societies. Sage Publications: Thousand Oaks.

Jones, E. (2002). Politics beyond accommodation? The May 2002 Dutch parliamentary elections. Dutch Crossing, 26, 61-78.

Kahn, R.L., Wolfe, D.M., Quinn, R.P., Snoek, J.D., \& Rosenthal, R.A. (1964). Organizational Stress: Studies in Role Conflict and Ambiguity. Wiley: New York. Kark, R., Waismel-Manor, R., \& Shamir, B. (2012). Does valuing androgyny and femininity lead to a female advantage? The relationship between gender-role, transformational leadership and identification. Leadership Quarterly, 23: 620640. http://dx.doi.org/10.1016/j.leaqua.2011.12.012

Koh, C., Fernando, M., \& Spedding, T. (2018). Exercising responsible leadership in a Singapore context. Leadership and Organizational Development Journal, 39(1), 34-50. http://dx.doi.org/10.1108/LODJ-09-2015-0215

Locke, R.R., \& Spender, J.C. (2011). Confronting Managerialism: How the Business Elites and the Business Schools Threw Our Lives Out of Balance. New York: Zed Books.

Lord, R.G., Brown, D.J., \& Freiberg, S.J. (1999). Understanding the dynamics of leadership: the role of follower self-concepts in the leader/follower relationship. 
Organizational Behavior and Human Decision Processes, 78, 167-203. http://dx.doi.org/10.1006/obhd.1999.2832

Luhmann, N. (2017). Trust and Power. Cambridge, UK: Wiley.

Magsaysay, J.F., \& Hechanova, M.R.M. (2017). Building an implicit change leadership theory. Leadership \& Organizational Development Journal, 38(6), 834-848 http://dx.doi.org/10.1108/LODJ-05-2016-0114

Milikowski, M. (2000). Exploring a model of de-ethnicization: the case of Turkish Television in the Netherlands. European Journal of Communication, 15, 443468. http://dx.doi.org/10.1177/0267323100015004001

Miller, K.D. (1992). A framework for integrated risk management in International Business. Journal of International Business Studies, 23, 311-331. http://dx.doi.org/10.1057/palgrave.jibs.8490270

Mullins, L.J. (2002). Management and Organisational Behavior. London: Prentice Hall.

Peet, J. (2002). Model makers: Model measurement, The Economist, Economist Intelligence Unit, May 4. http://www.economist.com/node/1098153/ Accessed 15 April 2018.

Pellegrini EK and Scandura, TA (2006) Leader-Member Exchange (LMX), paternalism, and delegation in the Turkish business culture: An Empirical investigation. Journal of International Business Studies 37, 264-279. http://dx.doi.org/10.1057/palgrave.jibs.8400185

Pellikaan, H., Van Der Meer, T., \& De Lange, S. (2003). The road from a depoliticised to a centrifugal democracy. Acta Politica, 38, 23-49.

Pley, H. (1998). De Kunst van het Gedogen. In Hollands Welbehagen, Bakker B (ed.). Amsterdam: Prometheus, 37-40.

Powell, G.N., Butterfield, D.A., \& Parent, J.D. (2002). Gender and managerial stereotypes: have the times changed? Journal of Management, 28, 177-193. http://dx.doi.org/10.1177/014920630202800203

Schama, S. (1988). The Embarrassment of Riches: An Interpretation of Dutch Culture in the Golden Age. University of California Press: Berkeley.

Schreuder, Y. (2001). The Polder Model in Dutch economic and environmental planning. Bulletin of Science, Technology and Society, 29, 237-245. http://dx.doi.org/10.1177/027046760102100401

Selvarajah, C., \& Meyer, D. (2017). Human capacity development in Indonesia: leadership and managerial ideology in Javanese organisations. Asia Pacific Business Review. 23(2), 264-289. http://dx.doi.org/10.1080/13602381.2017.1299401 
Selvarajah, C., Meyer, D., Roostika, R. \& Sukunesan, S. (2017) Exploring managerial leadership: Engaging Asta Brata, the eight principles of Indonesian statesmanship. Asia-Pacific Business Review, 23(3), 373-395.

Selvarajah, C., \& Meyer, D. (2006). Archetypes of the Malaysian manager: exploring ethnicity dimensions that relate to leadership. Journal of Management and Organization, 12, 251-269. http://dx.doi.org/10.5172/jmo.2006.12.3.251

Selvarajah, C., \& Meyer, D. (2008a). One nation, three cultures: exploring dimensions that relate to leadership in Malaysia. Leadership and Organization Development Journal, 29, 693-712. http://dx.doi.org/10.1108/01437730810916640

Selvarajah, C., \& Meyer, D. (2008b). Profiling the Chinese manager: exploring dimensions that relate to leadership. Leadership and Organization Development Journal, 29, 359-375. http://dx.doi.org/10.1108/01437730810876159

Selvarajah, C., Duignan, P., Suppiah, C., Lane, T., \& Nuttman, C. (1995). In search of the Asian leader: an exploratory study of dimensions that relates to excellence in leadership. Management International Review: Journal of International Business, 35, 29-34.

Selvarajah, C., Meyer, D., \& Davuth, D. (2012). The effect of cultural modelling on leadership profiling of the Cambodian manager. Asia Pacific Business Review, 18, 1-26. http://dx.doi.org/10.1080/13602381.2012.690256

Selvarajah, C., Meyer, D., \& Donovan, J. (2013a). Cultural context and its influence on managerial leadership in Thailand. Asia Pacific Business Review, 19, 356-380. http://dx.doi.org/10.1080/13602381.2012.714630

Selvarajah, C., Meyer, D., Jeyakumar, R., \& Donovan, J. (2013b). Flowers in a glasshouse: profiling excellence in leadership in Singapore. Leadership and Organization Development Journal, 34, 784-804.

Selvarajah, C., Meyer, D., Sukunesan, S., \& Venkatapathy, R. (2014). Rise of Indian firms: understanding leadership in Indian organizations. In: Chan TS, Cui G (eds.) The Rise of Asian Firms. London: Routledge, 91-119 http://dx.doi.org/10.1057/9781137407719_5

Selvarajah, C., Meyer, D., Vinen, D., \& Trung, P. (2010). In search of excellence in leadership in the Vietnamese manager: where Confucianism meets Dharma. Paper presented at the Academy of International Business (AIB) SEA Conference, Ho Chi Minh City, Vietnam.

Shrivastava, S., Selvarajah, C., Meyer, D., \& Dorasamy, N. (2014) Exploring excellence in leaderships amongst South African managers. Human Resource Development International, 17, 47-66. 
Siemsen, E., Roth, A., \& Oliveira, P. (2010). Common method bias in regression models with linear, quadratic, and interaction effects. Organizational Research Methods, 13, 456-476. http://dx.doi.org/10.1177/1094428109351241

Singh, N. (2002). From cultural models to cultural categories: a framework for cultural analysis. In: Broniarczyk SM, Nakamoto K. (eds) Advances in Consumer Research. GA Valdosta: Association for Consumer Research, 239-240.

Sterling, T. (2013). Dutch 'Polder Model' of sharing pain helps country agree on austerity in economic downturn. Times Colonist, January 25. http://www.timescolonist.com/business/dutch-polder-model-of-sharing-painhelps-country-agree-on-austerity-in-economic-downturn-1.56156/ Accessed 19 May 2018.

Taormina, R.J. \& Selvarajah, C. (2005). Perceptions of leadership excellence in ASEAN nations. Leadership 299-322. http://dx.doi.org/10.1177/1742715005054439

Thierry, H., den Hartog, D.N., Koopman, P.L., \& Wilderom, C.P.M. (2008). Culture and leadership in a flat country: The case of the Netherlands. In: Chhokar JS, Brodbeck FC, and House RJ. (eds) Culture and leadership across the world: The GLOBE book of in-depth studies of 25 societies. New York: Psychology Press, 215-249.

Torelli, C.J., \& Shavitt, S. (2010). Culture and concepts of power. Journal of Personal and Social Psychology, 99, 703-723. http://dx.doi.org/10.1037/a0019973

Trompenaars, A., \& Hampden-Turner, C. (2009). Riding the Waves of Culture: Understanding Diversity in Global Business. New York: McGraw-Hill.

Wallace. J., Mathias, M., \& Brotchie, J. (2013). Weathering the storm? A look at small countries' public service in times of austerity. http://www.carnegieuktrust.org.uk/getattachment/9a28dc44-4c41-4dc6-9e02fd40749cdc7a/Weathering-the-Storm---Full-Report.aspx/ Accessed 19 May 2018. Welzel, C. (2013). Freedom Rising: Human Empowerment and the Quest for Emancipation. Cambridge: Cambridge University Press. http://dx.doi.org/10.1017/CBO9781139540919

White, K., Carvalho, T., \& Riordan, S. (2011). Gender, power and managerialism in universities. Journal of Higher Education Policy and Management, 33, 179-188. http://dx.doi.org/10.1080/1360080X.2011.559631

Winsemius, P. (2010). Grote mensen gaan niet dood. Over het Nederland van volgende generaties. Amsterdam: Balans.

Wittfogel, K. (1957). Oriental Despotism: A Comparative Study of Total Power. New Haven: Yale University Press. 
Woldendorp, J., \& Keman, H. (2007). The Polder Model Reviewed: Dutch Corporatism 1965-2000. Economic and Industrial Democracy, 28(3), 317-347.

\section{APPENDIX}

Table A1 Statements to Identify Excellent Leadership (EL)

\begin{tabular}{lllc}
\hline \multicolumn{1}{c}{ Value statement } & Loading & Mean & SD \\
\hline EL1. Have confidence when dealing with work and people & 0.628 & 4.43 & 0.609 \\
EL2. Give recognition for good work & 0.615 & $\mathbf{4 . 6 3}$ & 0.533 \\
$\begin{array}{l}\text { EL3. Create a sense of purpose and enthusiasm in the } \\
\quad \text { workplace }\end{array}$ & 0.601 & 4.44 & 0.659 \\
EL4. Motivate employees & 0.569 & 4.51 & 0.632 \\
EL5. Continue to learn how to improve performance & 0.509 & 4.19 & 0.729 \\
EL6. Have a strategic vision for the organization & 0.454 & 4.37 & 0.694 \\
EL7. Organize work time effectively & .425 & 4.16 & 0.706 \\
EL8. Be honest & 0.412 & $\mathbf{4 . 6 5}$ & 0.568 \\
\hline
\end{tabular}

Normed Chi-square $=2.199 ;$ GFI $=0.99 ;$ AGFI $=0.98 ;$ CFI $=0.98 ;$ TLI $=0.97 ;$ RMSEA $=0.039$; SRMR $=0.040$

Table A2 Characteristics in The Environmental Influences (EI) Dimension

\begin{tabular}{lllc}
\hline \multicolumn{1}{c}{ Value statement } & Loading & Mean & SD \\
\hline EI1. Have a multicultural orientation and approach & 0.596 & 3.62 & 0.994 \\
EI2. Be socially and environmentally responsible & 0.526 & $\mathbf{4 . 1 4}$ & 0.733 \\
$\begin{array}{l}\text { EI3. Identify social trends which may have an impact on the } \\
\quad \text { work }\end{array}$ & 0.594 & 3.93 & 0.708 \\
EI4. Constantly evaluate emerging technologies & 0.306 & 3.31 & 0.935 \\
EI5. Use economic indicators for planning purposes & 0.389 & 3.61 & 0.855 \\
EI6. Be responsive to political realities in the environment & 0.354 & 3.84 & 0.846 \\
\hline
\end{tabular}

Normed Chi-square $=2.241 ; \mathrm{GFI}=0.99 ; \mathrm{AGFI}=0.98 ; \mathrm{CFI}=0.98 ; \mathrm{TLI}=0.97 ; \mathrm{RMSEA}=0.039$; SRMR $=0.029$ 
Table A3 Characteristics in the Personal Qualities (PQ) Dimension

\begin{tabular}{|c|c|c|c|}
\hline Value statements & Loading & Mean & SD \\
\hline Respect the self-esteem of others & 0.578 & 4.45 & 0.597 \\
\hline Be consistent in dealing with people & 0.553 & 4.32 & 0.725 \\
\hline Be dependable and trustworthy & 0.548 & 4.79 & 0.464 \\
\hline PQ4. Accept responsibilities for mistakes & 0.532 & 4.53 & 0.611 \\
\hline PQ5. Deal calmly in tense situations & 0.521 & 4.22 & 0.665 \\
\hline PQ7. Listen to the advice of others & 0.466 & 4.14 & 0.666 \\
\hline PQ8. Return favours & 0.456 & 3.46 & 0.914 \\
\hline PQ9. Write clearly and concisely & 0.445 & 3.95 & 0.747 \\
\hline $\begin{array}{l}\text { PQ10. Follow what is morally right, not what is right for } \\
\text { self or for the organization }\end{array}$ & 0.423 & 3.40 & 0.949 \\
\hline PQ11. Accept that others will make mistakes & 0.403 & 4.28 & 0.723 \\
\hline PQ12. Have a sense of humour & 0.398 & 4.05 & 0.713 \\
\hline PQ13 Be an initiator, not a follower & 0.376 & 4.24 & 0.727 \\
\hline
\end{tabular}

Table A4. Characteristics in the Organizational Demands (OD) Dimension

\begin{tabular}{lllll}
\hline & Value statements & Loading & Mean & SD \\
\hline OD1. & Share power & 0.557 & 3.58 & 0.953 \\
OD2. & Support decisions made jointly by others & 0.557 & 4.04 & 0.747 \\
OD3. & Focus on maximising productivity & 0.386 & 3.65 & 0.793 \\
OD4. & Sell the professional or corporate image to the public & 0.611 & 4.14 & 0.795 \\
OD5. Act as a member of the team & 0.443 & 4.36 & 0.721 \\
OD6. & Give priority to long-term goals & 0.396 & 3.93 & 0.759 \\
OD7. Adjust organizational structures and rules to realities & 0.346 & 3.65 & 0.874 \\
& & & & \\
\hline
\end{tabular}

Normed Chi-square $=1.525 ; \mathrm{GFI}=0.99 ; \mathrm{AGFI}=0.98 ; \mathrm{CFI}=0.99 ; \mathrm{TLI}=0.98 ; \mathrm{RMSEA}=0.026$; SRMR $=0.023$ 
Table A5 Characteristics in The Managerial Behaviors (MB) Dimension

\begin{tabular}{lllll}
\hline & Value statements & Loading & Mean & SD \\
\hline MB1. & Select work wisely to avoid overload & 0.518 & 3.69 & 0.836 \\
MB2. & Focus on the task-at-hand & 0.496 & 3.56 & 0.823 \\
MB3. & Listen to and understand the problems of others & 0.496 & 4.10 & 0.709 \\
MB4. & Be logical in solving problems & 0.429 & 3.90 & 0.751 \\
MB5. & Persuade others to do things & 0.419 & 3.54 & 0.814 \\
MB6. & Make decisions earlier rather than later & 0.369 & 3.45 & 0.859 \\
MB7. & Trust those to whom work is delegated & 0.405 & $\mathbf{4 . 3 8}$ & 0.622 \\
MB8. & Keep up-to-date on management literature & .396 & 3.24 & 0.946 \\
MB9. & Delegate & 0.360 & $\mathbf{4 . 2 7}$ & 0.666 \\
\hline
\end{tabular}

Normed Chi-square $=2.808 ; \mathrm{GFI}=0.98 ; \mathrm{AGFI}=0.96 ; \mathrm{CFI}=0.92 ; \mathrm{TLI}=0.90 ; \mathrm{RMSEA}=0.047$; SRMR $=0.040$ 
